\title{
THE PRESIDENT
}

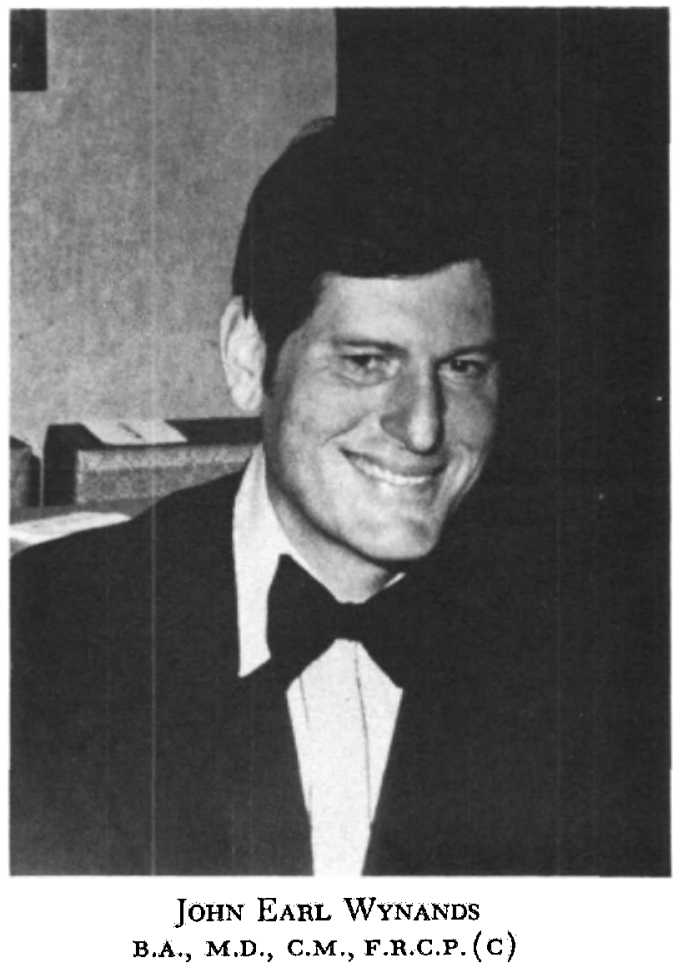

Dr. J.E. Wynands was installed as President of The Canadian Anaesthetists' Society during the Annual Meeting at St. John's, Newfoundland, in June 1974.

Dr. Wynands was born in Montreal on December 10,1929. He was educated at Loyola College (B.A. 1950) and McGill University (M.D., C.M., 1954). After an internship at St. Vincent's Hospital in Bridgeport, Connecticut, he returned to Montreal to enrol in the Diploma Course in Anaesthesia at McGill University. On completion of his training he was Certificated in Anaesthesia by the Royal College of Physicians and Surgeons of Canada and by the College of Physicians and Surgeons of the Province of Quebec. He then joined the staff of the Department of Anaesthesia at the Royal Victoria Hospital in Montreal, as a Clinical Assistant. In 1961 he became Assistant Anaesthetist at the Royal Victoria and was appointed Demonstrator in Anaesthesia at McGill University. He became Senior Anaesthetist at the Royal Victoria Hospital in 1971, and was promoted to the rank of Associate Professor at McGill in 1973. He became a Fellow of the Royal College of Physicians and Surgeons of Canada in 1972.

During his career Dr. Wynands has had a special interest in Anaesthesia for Cardiac Surgery, and was a founding member of the Association of Cardiac Anaesthesiologists at Boston in 1972. He has been the author or co-author of a number of significant publications in his specialty.

Dr. Wynands has been active for many years in the Quebec Division of The Canadian Anaesthetists' Society, and represented that Division on Council from 1969 to 1972. He was elected to be 2nd Vice-President in 1972 and 1st Vice-President in 1973.

Dr. Wynands was married to Mary Grant in 1954. They are the proud parents of four boys and two girls. While Montreal is officially home, they also live down on the farm, which produces maple syrup in the spring, apples in the fall, and country quiet and fresh air the year round. 
The Society can look forward to an active and stimulating year under the leadership of Earl Wynands.

\author{
John EARL Wynands \\ B.A., M.D., C.M., F.R.C.P. (C)
}

Le Dr Wynands est entré en fonction à titre de Président de la Société Canadienne des Anesthésistes au cours de la réunion annuelle de la Société, tenue à Ste Jean, Terreneuve en juin 1974 .

Né à Montréal, le 10 décembre 1929, il y fit ses études secondaires au Collège Loyola (B.A., 1950) et médicales à l'Université McGill (M.D., C.M., en 1954). Après son internat fait à l'hôpital St. Vincent de Bridgeport, Connecticut, il revient à Montréal et s'inscrit au "Diploma Course in Anaesthesia" de l'Université McGill. Après obtention de son certificat de spécialiste en Anesthésie du Collège Royal et de la Province de Québec, il devient membre du Département d'Anesthésie de l'Hôpital Royal Victoria à titre d'Assistant Clinique. En 1961 il est nommé Anesthésiste Assistant au Royal Victoria et "Démonstrateur" en Anesthésie à l'Université McGill. En 1971, il devient Anesthésiste Sénior à l'Hôpital Royal Victoria; un an plus tard, il obtient le titre de Fellow du Collège Royal des Médecins et Chirurgiens du Canada et, en 1973, il est promu au rang de Professeur Associé à McGill.

Durant sa carrière, le Dr Wynands s'est interessé de façon particulière à l'anesthésie pour chirurgie cardiaque et fut l'un des membres fondateurs de l'Association des Anesthésiologistes Cardiaques, en 1972 à Boston.

Il à signé de nombreuses et importantes publications scientifiques, soit comme auteur principal ou comme co-auteur. Il a participé plusieurs années aux travaux de la Section du Québec de la Société Canadienne des Anesthésistes, section qu'il a représentée au Conseil National de 1969 à 1972. Il fut élu Second puis Premier Vice-Président de notre association en 1972 et en 1973.

Il s'est marié à Mary Grant en 1954. Ils sont les fiers parents de quatre fils et de deux filles. Bien que Montréal soit leur lieu de résidence officiel, ils s'évadent fréquemment sur leur ferme où, en plus de faire ample provision d'air pur, ils fabriquent du sirop d'érable au printemps et font la récolte des pommes en automne.

La Société envisage une année active et stimulante sous la direction du Dr Wynands. 